\title{
Front Matter: Volume 11368
}

, "Front Matter: Volume 11368," Proc. SPIE 11368, Photonics and Plasmonics at the Mesoscale, 1136801 (24 April 2020); doi: 10.1117/12.2571806

SPIE. Event: SPIE Photonics Europe, 2020, Online Only 


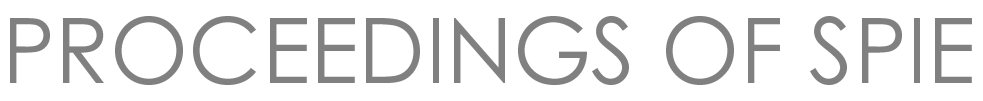

\title{
Photonics and Plasmonics at the Mesoscale
}

\author{
Sylvain Lecler \\ Vasily N. Astratov \\ Igor V. Minin \\ Editors \\ 6-10 April 2020 \\ Online Only, France \\ Sponsored by \\ SPIE \\ Cosponsored by \\ City of Strasbourg (France) \\ Eurometropole (France) \\ CNRS (France) \\ Région Grand Est (France) \\ iCube (France) \\ Université de Strasbourg (France) \\ Cooperating Organisations \\ Photonics 21 (Germany) \\ EOS-European Optical Society (Germany) \\ Photonics Public Private Partnership (Belgium) \\ Photonics France (France) \\ Published by \\ SPIE
}

Volume 11368 
The papers in this volume were part of the technical conference cited on the cover and title page. Papers were selected and subject to review by the editors and conference program committee. Some conference presentations may not be available for publication. Additional papers and presentation recordings may be available online in the SPIE Digital Library at SPIEDigitalLibrary.org.

The papers reflect the work and thoughts of the authors and are published herein as submitted. The publisher is not responsible for the validity of the information or for any outcomes resulting from reliance thereon.

Please use the following format to cite material from these proceedings:

Author(s), "Title of Paper," in Photonics and Plasmonics at the Mesoscale, edited by Sylvain Lecler, Vasily N. Astratov, Igor V. Minin, Proceedings of SPIE Vol. 11368 (SPIE, Bellingham, WA, 2020) Sevendigit Article CID Number.

ISSN: 0277-786X

ISSN: 1996-756X (electronic)

ISBN: 9781510635081

ISBN: 9781510635098 (electronic)

Published by

SPIE

P.O. Box 10, Bellingham, Washington 98227-0010 USA

Telephone +1 3606763290 (Pacific Time) · Fax +1 3606471445

SPIE.org

Copyright (C) 2020, Society of Photo-Optical Instrumentation Engineers.

Copying of material in this book for internal or personal use, or for the internal or personal use of specific clients, beyond the fair use provisions granted by the U.S. Copyright Law is authorized by SPIE subject to payment of copying fees. The Transactional Reporting Service base fee for this volume is $\$ 18.00$ per article (or portion thereof), which should be paid directly to the Copyright Clearance Center (CCC), 222 Rosewood Drive, Danvers, MA 01923. Payment may also be made electronically through CCC Online at copyright.com. Other copying for republication, resale, advertising or promotion, or any form of systematic or multiple reproduction of any material in this book is prohibited except with permission in writing from the publisher. The CCC fee code is $0277-$ $786 \times / 20 / \$ 18.00$.

Printed in the United States of America.

Publication of record for individual papers is online in the SPIE Digital Library.

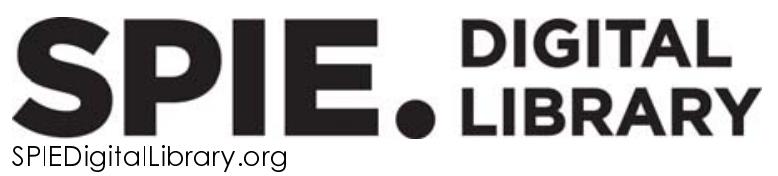

Paper Numbering: Proceedings of SPIE follow an e-First publication model. A unique citation identifier (CID) number is assigned to each article at the time of publication. Utilization of CIDs allows articles to be fully citable as soon as they are published online, and connects the same identifier to all online and print versions of the publication. SPIE uses a seven-digit CID article numbering system structured as follows:

- The first five digits correspond to the SPIE volume number.

- The last two digits indicate publication order within the volume using a Base 36 numbering system employing both numerals and letters. These two-number sets start with 00, 01, 02, 03, 04, 05, 06, 07, 08, 09, OA, OB ... 0Z, followed by 10-1Z, 20-2Z, etc. The CID Number appears on each page of the manuscript. 


\section{Contents}

$\checkmark \quad$ Authors

vii Conference Committee

WHISPERING GALLERY MODES AND APPLICATIONS

$1136802 \quad$ Hybrid system of different shapes of gold nanoparticles on microcavity to study Purcell's effect (Invited Paper) [1 1368-1]

1136804 Scatterer induced Fano resonances in WS 2 coated microsphere resonator [11368-3]

PHOTONIC JETS AND UNCONVENTIONAL BEAMS

1136806 Tuning the photonic nanojet based on the Babinet principle (Invited Paper) [1 1368-5]

$1136807 \quad$ Electromagnetic field localization behind a mesoscale dielectric particle with a broken symmetry: a photonic hook phenomenon (Invited Paper) [11368-6]

$1136809 \quad$ Nanojet-based dielectric multi-material color splitters for image sensor applications [1 1368-8]

$113680 \mathrm{~A}$ Structuring non-diffracting hollow beams within micrometer spatial domains [11368-9]

PLASMONICS AND METAMATERIALS

11368 OB Development of mesoscale photonics and plasmonics: a tribute to the jubilee of Professors Igor V. Minin and Oleg V. Minin [11368-14]

POSTER SESSION

11368 OE Tailoring light absorption of plasmonic-doped spherical dielectric microcapsule (Invited Paper) [11368-11]

$11368 \mathrm{OF} \quad$ Exploiting plasmon resonances in a composite photonic crystal for polarization-sensitive dichroic filtering (Invited Paper) [11368-12] 
Proc. of SPIE Vol. 11368 1136801-4 Downloaded From: https://www.spiedigitallibrary.org/conference-proceedings-of-spie on 26 Apr 2023
Terms of Use: https://www.spiedigitallibrary.org/terms-of-use 


\section{Authors}

Numbers in the index correspond to the last two digits of the seven-digit citation identifier (CID) article numbering system used in Proceedings of SPIE. The first five digits reflect the volume number. Base 36 numbering is employed for the last two digits and indicates the order of articles within the volume. Numbers start with 00, 01, 02, 03, 04, 05, 06, 07, 08, 09, 0A, 0B...0Z, followed by 10-1Z, 20-2Z, etc.

Agrawal, Tulika, 02

Allié, Valérie, 09

Bentivegna, Florian F. L., OF

Bhattacharya, Shubhayan, 02, 04

Bisht, Prem B., 02, 04

Blondé, Laurent, 09

Dadoenkova, Yuliya S., OF

Drazic, Valter, 09

Geints, Yury E., OE

Glukhov, Igor A., OF

Huang, C. C., 04

Karabchevsky, Alina, 06, OB

Katyba, G. N., 07

Keren, Yaakov, 06

Kurlov, V. N., 07

Minin, Igor $\vee ., 06,07$

Minin, Oleg $\vee ., 06,07$

Moiseev, Sergey G., OF

Murugan, Ganapathy Senthil, 02, 04

Panina, Ekaterina K., OE

Shramkova, Oksana, 09

Singh, Gurvinder, 02

Varghese, Bobin, 09

Veluthandath, Aneesh Vincent, 02, 04

Wang, Z., 07

Yue, L., 07

Zamboni-Rached, Michel, OA

Zayłsev, K. I., 07

Zemlyanov, Alexander A., OE

Zreiqat, Hala, 02 
Proc. of SPIE Vol. 11368 1136801-6

\section{Downloaded From: https://www.spiedigitallibrary.org/conference-proceedings-of-spie on 26 Apr 2023 Terms of Use: https://www.spiedigitallibrary.org/terms-of-use}




\section{Conference Committee}

Symposium Chairs

Francis Berghmans, Vrije Universiteit Brussel (Belgium)

Thierry Georges, Oxxius SA (France)

Paul Montgomery, Université de Strasbourg (France)

Lluis Torner, ICFO Barcelona (Spain)

Conference Chairs

Sylvain Lecler, Laboratoire des sciences de l'Ingénieur, de

I'Informatique et de l'Imagerie (France)

Vasily N. Astratov, The University of North Carolina at Charlotte (United States)

Igor V. Minin, National Research Tomsk State University

(Russian Federation)

Session Chairs

1 Whispering Galery Modes and Applications

Sylvain Lecler, ICube (France)

2 Photonic Jets and Unconventional Beams

Igor V. Minin, National Research Tomsk State University

(Russian Federation)

3 Plasmonics and Metamaterials

Sylvain Lecler, ICube (France)

Igor V. Minin, National Research Tomsk State University

(Russian Federation) 
Proc. of SPIE Vol. 11368 1136801-8

Downloaded From: https://www.spiedigitallibrary.org/conference-proceedings-of-spie on 26 Apr 2023
Terms of Use: https://www.spiedigitallibrary.org/terms-of-use 